\title{
Using Geographic Information System to Analyze Dryland Pattern in Wringin Subdistrict, Bondowoso Regency
}

\author{
$1^{\text {st }}$ Rahmad Faizal \\ Universitas Negeri Malang \\ Malang, Indonesia \\ rahmadfaizal51@gmail.com \\ $2^{\text {nd }}$ Nevy Farista Aristin \\ Doctoral Program Education of Geography \\ Universitas Negeri Malang \\ Malang, Indonesia \\ nevyfarista@ulm.ac.id
}

\author{
$3^{\text {rd }}$ Agus Purnomo \\ Social Studies Program \\ Universitas Negeri Malang \\ Malang, Indonesia \\ agus.purnomo.fis@um.ac.id \\ $4^{\text {th }}$ Dayinta Dwi Nimpuna \\ Universitas Negeri Malang \\ Malang, Indonesia
}

\begin{abstract}
Dryland is a potential land for development of the agriculture sector in Indonesia. Bondowoso is one of the districts that have the potential to dry land for the agricultural sector. Agricultural sectors such as commodities superior cassava plant. One of the largest producer of cassava in Wringin Subdistrict. To support the commodity cassava in Wringin Subdistrict will require optimal use of dry land. The purpose of this study is a map of dry land-use patterns to support the cassava plants in the Wringin Subdistrict. These results indicate that the Wringin Subdistrict have dry land scattered throughout the district with 3976.06 Ha. The dry land area used as the moor at 3464.28 Ha. The use of this moor will be supported agriculture cassava plant as the leading commodity in the Wringin Subdistrict.
\end{abstract}

Keywords: dryland, moor, geographic information systems

\section{INTRODUCTION}

Dryland is that has a strategic potential in agricultural development in Indonesia. Optimal utilisation of dry land to use as a way to equalise the development of the agricultural sector. Dryland is a producer of various agricultural commodities such as food, clothing, estate, housing, medicine, as well as a foreign exchange earner [1]. The economy in Bondowoso is dominated by agriculture, forestry and fisheries. Based on agricultural sector in the three main sub-sectors, namely (a) the agriculture subsector, (b) the forestry subsector, (c) the fisheries subsector. The highest state of the economy this subsector derived from agriculture sector amounted to $93.72 \%$, consisting of sub-sectors of food crops, horticultural crops, plantation, animal husbandry, and agriculture and hunting services. Sub-sub-sectors of food crops that have the most significant contribution to Gross Domestic Product (GDP) amounted to $45.41 \%$. It can conclude that sub-subsectors of food crops used as the foundation in the development of the regional economy in the regency.

Wringin subdistrict is one of the Bondowoso regency which has the potential of natural resources in the agricultural sector is very large. Agricultural potential in the Wringin Subdistrict dominated by cassava which serves as the leading commodity [2], Their economic potential in an area does not have important role if not used and developed optimally [3], To develop the cassava plant requires the support of a potential dry land in the region. The purpose of this study was to map of the dry land use patterns to support the cassava plants in the Wringin Subdistrict.

\section{METHOD}

The research was conducted in the Wringin Subdistrict the regency which has an area of $58.01 \mathrm{~km} 2$. Map of the area of this study presented in fig 1. This study uses spatial analysis with Geographic Information Systems. Data used in this research is secondary data. The data used by using the Aster DEM USGS Earth Explorer and RBI Digital Map InaGeoportal of Bondowoso Regency for the determination of dry land use in the Wringin Subdistrict (fig 1). 


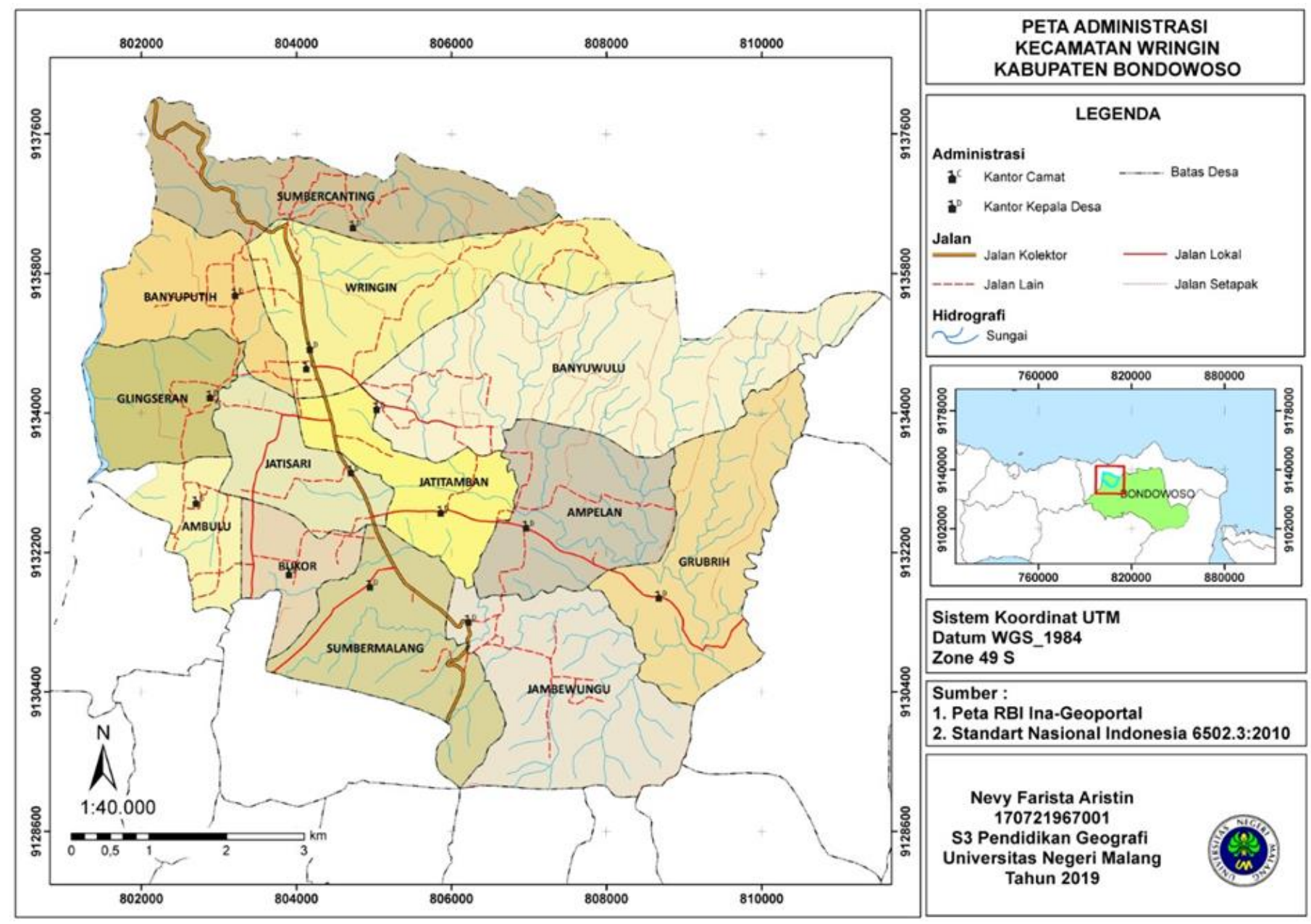

Figure 1. Map of Study Area Wringin Subdistrict

\section{RESUltS AND DISCUSSION}

Dryland is the land where the plant needs water supply depends entirely on rainwater [4] that never flooded or flooded at most times of the year or throughout the year [5]. Wringin sub-district is one of the districts in the regency which has an area of $58.01 \mathrm{~km} 2$. Wringin Subdistrict has topography of mountains and hills with a slope of $3-15 \%$ and $16-40 \%$. Grouping of dry land on the type of land use divided into dryland farming and other farms. Dryland farming consists of fields/gardens, pastures, land that not cultivated, private forest land and plantations. Other farms consisting of yard building, marshes, ponds and pools/ponds [6].

The dry land use of Wringin Subdistrict result with spatial analysis with Geographic Information Systems can see in Table 1. Dryland use is dominated by moor at $3464.28 \mathrm{Ha}$.
TABLE I. USE OF DRYLAND DISTRICT OF WRINGIN 2016STYLES

\begin{tabular}{|l|l|l|}
\hline No. & \multicolumn{1}{|c|}{ Type Use of Dryland } & \multicolumn{1}{|c|}{ Area (Ha) } \\
\hline 1 & Thicket/shrubs & 506.81 \\
\hline 2 & Garden & 4.96 \\
\hline 3 & Moor & 3464.28 \\
\hline & Total & 3976.06 \\
\hline
\end{tabular}

The results of the processed data presented on a map of dry land use in Wringin Subdistrict presented in fig 2. In the Wringin Subdistrict, Moor mostly located on the slope $<5 \%$ (flat) and $15-$ $25 \%$ (hilly). Lowland dry land is generally flat, wavy, wavy undulating and hilly, while the upland generally undulating, hilly to mountainous [5]. Generally, the steep slope dry land highly susceptible to erosion, mainly if cultivated for food crops season. Limitations of the water on dry land also resulted farming can not done all year round [7]. The use of dry land in 


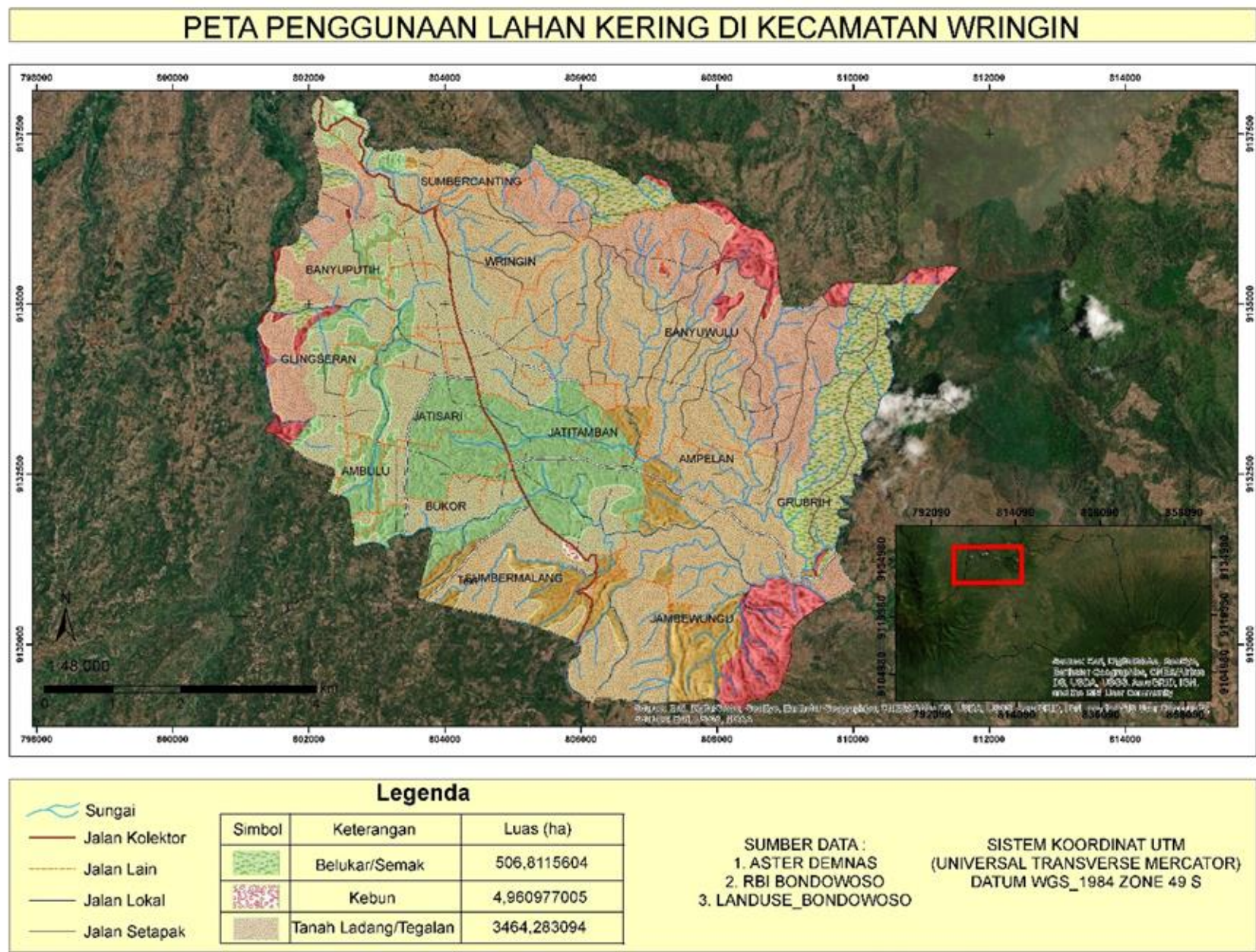

Figure 2. Map of Dry Land Use in Wringin Subdistrict

the Wringin Subdistrict which is optimal, so it will be supporting cassava plants as in fig 3 .

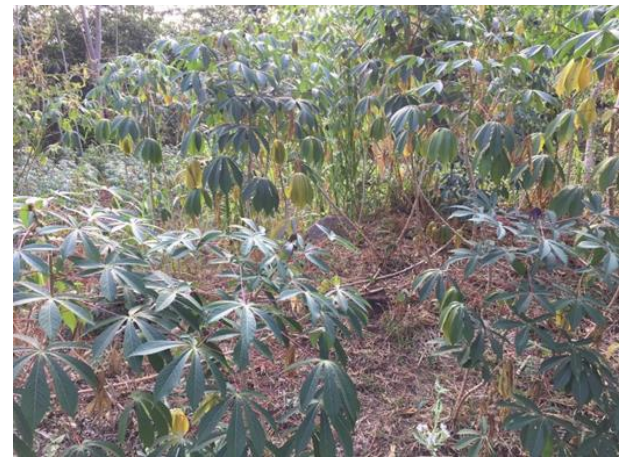

Fig 3. The Dry Land Use for Cassava Plants in Wringin Subdistrict
The cassava plant is a leading commodity District of Wringin. Food crops such as cassava basis in Wringin Subdistrict [2]. This condition is supported by the amount of cassava production in Wringin Subdistrict 2017 amounted to 40,081 tonnes [8]. Dryland management especially moor can later be optimised to support agriculture in Wringin Subdistrict.

\section{CONCLUSION}

Wringin Subdistrict land use dominated by dry land scattered throughout the district with an area 3976.06 Ha. The use of dry land consists of thicket/shrubs, gardens and moor. The land use used as a moor that has $3464.28 \mathrm{Ha}$. The use of this moor will be support agriculture of cassava plant as the leading commodity in the Wringin Subdistrict. 


\section{ACKNOWLEDGMENT}

Acknowledgements to the Government of the regency, the District Chief Wringin, and BPPDN-DIKTI.

\section{REFERENCES}

[1] K. Wikantika and A. A, "Analisis Perubahan Luas Pertanian Lahan Kering Menggunakan Transformasi Tasseled Cap (Studi Kasus Kawasan Puncak-Jawa Barat)," Jurnal Infrastruktur dan Lingkungan Binaan, vol. II, no. 1, 2006.

[2] S. Qomariyah, Mustapit and A. Supriono, "Analisis Potensi Wilayah Berbasis Komoditas Pertanian Tanaman Pangan Serta Kontribusinya Terhadap Perekonomian Kabupaten Bondowoso," JSEP, vol. 11, no. 1, pp. 66-72, 2018.

[3] J. Nikijuluw, "Analisis Sektor ekonomi Unggulan Kabupaten/Kota Di Propinsi Maluku," Cita Ekonomika, vol. VII, no. 2, pp. 196-303, 2013.
[4] I. Kadekoh, "Optimalisasi Pemanfaatan Lahan Kering Berkelanjutan Dengan Sistem Polikultur," in Seminar Nasional Pengembangan Inovasi Lahan Marginal, Sulawesi Tengah, 2007.

[5] P. P. d. P. T. d. Agroklimat, Teknlogi Pengelolaan Lahan Kering, Menuju Pertanian Produktif dan Ramah Lingkungan, Bogor: Badan Penelitian dan Pengembangan Pertanian, Departemen Pertanian, 2005.

[6] B. P. Statistik, Luas Lahan Menurut Penggunaannya, Jakarta: Badan Pusat Statistik, 2006.

[7] S. Minardi, "Optimalisasi Pengelolaan Lahan Kering Untuk Pengembangan Pertanian Tanaman Pangan," UNS, Surakarta, 2016.

[8] BPS Bondowoso, "Kecamatan Wringin Dalam Angka Tahun 2017," 2018. [Online]. Available: https://bondowosokab.bps.go.id/. [Accessed 03 Juli 2019]. 